\title{
Internal Financial Controls and Working Capital Management in Public Universities in Uganda: A Case Study of Makerere University Kampala
}

\author{
Eric Nzibonera ${ }^{1} \&$ James Ninsiima $^{1}$ \\ ${ }^{1}$ Department of Accounting \& Finance, School of Business, College of Business \& Management Sciences, Makerere \\ University, Kampala, Uganda \\ Correspondence: Eric Nzibonera, Department of Accounting \& Finance, School of Business, College of Business \& \\ Management Sciences, Makerere University, Kampala, Uganda.
}

Received: April 29, 2020

Accepted: May 18, 2020

Online Published: May 21, 2020

doi:10.5430/ijba.v11n3p72

URL: https://doi.org/10.5430/ijba.v11n3p72

\begin{abstract}
The objective of the study is to examine the extent to which internal financial controls affect working capital management in Public Universities in Uganda. Working capital is vital for running of institutions because it provides the financial liquidity needed to effectively manage day-today operations. A cross-sectional research design was adopted using a quantitative approach. Data was collected from staff of Finance and Internal Audit Directorates, and heads of Departments, Schools and Colleges of Makerere University using a self- administered closed ended questionnaire. Empirical data was analyzed using descriptive statistics, Pearson's correlation and regression tests. Findings indicate that the elements of internal financial controls which include; the control environment, risk assessment process and budget control have a positive and significant effect. The effect of control activities is not statistically significant. Therefore, Public Universities should strengthen financial control policies and procedures, risk assessment processes and budgetary control mechanisms to effectively manage working capital.
\end{abstract}

Keywords: financial controls, working capital, public universities

\section{Introduction}

Working capital is considered as a life-blood and nerve center of every enterprise and therefore, no organization can run effectively without adequate quantity of working capital (Tejmani \& Moirangthem, 2013). It is an integral part of corporate management and can be utilized for meeting short-term financial obligations and for maintenance of non-current assets that are involved in day-today operations of the enterprise. For efficient management of working capital, an organization needs a strong functioning internal financial control system. Internal financial controls are defined as procedures designed to protect assets and ensure that all financial transactions are recorded to prevent and reduce errors and fraud (Block \& Geoffrey, 2008). The aim of financial controls is to provide an overall guiding framework for a sound and efficient management of resources in all institutions. Effective financial controls including the maintenance of proper accounting records help ensure that the institution is not unnecessarily exposed to financial risks and that the financial information is used only within the business (Hayles, 2005). As per Section 134 of the Companies Act 2013 of Uganda, the term 'Internal Financial Controls' means the policies and procedures adopted by the company for ensuring orderly and efficient conduct of its business, including adherence to company's policies, safeguarding of its assets, prevention and detection of frauds and errors, accuracy and completeness of the accounting records, and timely preparation of reliable financial information. Therefore, a strong internal control system makes it possible to put in place policies that ensure that financial and other resources of an organization are efficiently used.

Financial resources are vital to many institutions and establishments (Allis et al., 2004). This means that financial resources which majorly comprise of working capital must be effectively and efficiently managed to bring about the needed change and results from the activity for which the funds have been made available. However, sometimes this important resource is mismanaged and misappropriated especially in the public sector by those put in charge (Wakiriba, Ngahu, Wagoki (2014). Public sector organizations deal with large amounts of public funds and operate in a largely political environment, thereby necessitating a need for a high degree of confidence in the way in which their financial affairs are conducted. Several companies have collapsed due to misappropriation or mismanagement of financial resources through fraudulent practices (Agyapong, 2017). It is for this reason that internal controls were introduced in the public sector for effective and efficient use of working capital resources. According to Sambo \& Benneth (2018) 
Public education institutions which are part of Public sector management, attract a lot of attention and funding from Government and therefore, it's important that internal systems are strengthened for effective use of these resources. The overall growth and development of a country depends on the success of education sector. Globally, the education sector plays a key role in providing skilled manpower and developing techniques and methodologies needed for growth of a country. However, in most developing nations, the basic needed financial resources are either not available or if available, are rather mismanaged or misappropriated.

In Uganda, there are eight Public Universities which are partly funded but fully owned by the State. They enroll both Government funded and privately funded students with the latter category of students charged fees that contribute to Non-Tax Revenue (BMAU Paper, 2018). Therefore, these Universities get funds from the Government, tuition fees charged to students, donations and private partnerships which highlight the diversified nature of the resource base to run day-today working capital operations. All these sources are treated as public funds because the nature of the institutions is denoted as public, albeit with varying levels of expenditure discretion. However, these financial resources are normally mismanaged and misappropriated leading to perpetual University strikes by students and staff (Wakiriba, Ngahu \& Wagoki, 2014). Furthermore, while other public agencies and ministries remit their 'non-tax' or internally generated funds to the consolidated fund, Public Universities spend their internal revenues at source in what has been termed as Appropriation in Aid (Nakayiwa, 2012). Utilization of these funds is based on The Public Universities Financial Management guidelines developed in 2009, with the rationale for addressing consistent systemic deficiencies noted by the Office of the Auditor General (OAG).These include failure of Universities to present their budgets for appropriation, insufficient disclosure of internally generated funds, poor book keeping and lack of standardization in accounting which have always bogged down Universities financial management (Auditor General, 2016).

For Makerere University, a report by Auditor General (2016) mentioned discrepancies in managing working capital especially payments of salaries and wages, management of University supplies, mischarge of expenditure and poor cash and bank reconciliations. Furthermore, Kyaligonza, Kimoga and Nabayego (2015) state that the report of the visitation committee to Public Universities in Uganda (2007) revealed that Makerere University failed to account for funds collected from private students and Mbarara University of Science and Technology which is also a Public University had no clear internal financial controls. These show inefficiencies in working capital management especially management of day-today cash balances and revenue receivables from tuition funds. Mismanagement of public funds needed for working capital operations in Public Universities creates a need for establishing and strengthening internal financial controls to enhance efficiency and proper accountability. The need for proper management of working capital funds is essential and internal financial controls system serves as an invaluable tool for proper accountability and management of public funds. Hence, the objective of this research is to evaluate the extent to which internal financial controls affect working capital management in Public Universities in Uganda. Specifically, the study aims; to assess the strength of the existing internal financial controls in public universities in Uganda and to establish the relationship between internal financial controls and working capital management in Public Universities in Uganda. The study contributes to literature on the effectiveness of internal financial controls in managing use of public funds needed for day-today operations in the public sector.

The structure of the paper comprises five areas which includes the following: The first part is the introduction which describes the general context and background information of the study. The second part is the theoretical and literature review which discusses the existing theories and literature about the effectiveness of internal financial controls in working capital management. The third area covers the study design and methodology. This describes the approach used, the sampling framework and methods of data collection, testing for validity and reliability of data collection instruments and the research model using the regression equation. The fourth part of the paper presents the discussion of main findings and the last part describes the conclusions, implications and the contribution of the study.

\section{Theoretical and Literature Review}

\subsection{Efficiency Theory}

This research is based on the efficiency theory developed by an American economist called Havey Leibenstein in the year 1993. Leibenstein (1993) observed that the general efficiency of a firm's management is found in its ability to transform inputs at minimum cost into maximum profit. This theory compares the inputs and output to establish the level of fairness in the efficient utilization of resources. This theory is applicable in the university system in that for the university system to effectively manage funds, internal financial control measures must be put in place to ensure that available resources are effectively and efficiently used in order to achieve the set goals and objectives. In some cases, it is not poor funding that is the problem but mismanagement, misappropriation and other fraudulent practices 
that are responsible for the lack of effective working capital management. Managers of public university funds need to be prudent in their financial control systems in order to manage available resources for proper working capital management.

\subsection{Institutional Theory}

The theory is associated with Blacke \& Moseley (2010) and is described from the perspectives of Max Weber's bureaucracy and Fredrick W Taylor theory of scientific management. It considers institutional systems as social organization structures with schemes, rules, norms, unit and chain of command, division of authority with established and authoritative guidelines which work towards strengthening control systems. The theory postulates that institutions should have mandate and well established systems to enable people work and minimize opportunistic human behavior. This improves operation systems and enhances management of working capital. The theory further explains how structures and systems of an organization are coordinated to improve operations of an organization and enhance effective use of organizational resources.

\subsection{Internal Financial Control}

Internal control is a continuous set of processes and procedures established by the governing board of directors of an enterprise, management and all personnel, designed to provide reasonable assurance of effectiveness and efficiency of operations (Gyebi \& Quain, 2013). The internal control system should be able to strengthen the operating environment of the entity to ensure compliance with laws, regulations, internal policies and procedures. The system should be able to uncover possible flaws and deficiencies in organizational processes and structures. The 1992 report of the Committee of Sponsoring organization (COSO) states that strengthening internal controls will provide assurance regarding the achievement of effectiveness and efficiency of entity's operations, reliability of financial reporting and compliance with applicable laws and regulations (Kalagbor, Nyime \& Aloy- Ezirim, 2018). COSO identified five elements of good internal financial control system. These include control environment, risk assessment, control activities, information and communication and monitoring. Budgetary controls are also regarded as mechanism of ensuring efficient operations and therefore regarded as financial controls. Companies with adequate financial controls are likely to have improved efficiency in management of working capital which ultimately enhances financial performance (Kabuye et al., 2019).

\subsection{Control Environment and Working Capital Management}

The control environment is the overall attitude, awareness and actions of management regarding internal controls and their importance in the entity. It involves management style, corporate culture, values, philosophy and operating style, organization structure, personnel policies and procedures. The control environment ensures availability of sound accounting and financial management systems or an effective internal control system as a whole (Woolf, 1994). The control environment is the structure within which controls operate. It helps in setting up control procedures and to ensure that the controls work effectively (Badoo, Hammond \& Oppong, 2020).

According to Whittington \& Pany (2004) the control environment sets the tone of the organization by influencing the control consciousness of people on entity financial performance. Control environment is considered to factors such as integrity and ethical values, commitment to competence of board of directors or audit committee, management's philosophy and operating style, organizational structure, assignment of authority and responsibility, and human resource policies and practices. Cohen (2002) argues that the control environment starts with the board of directors and management of a public entity, who set the tone of organization through policies, behavior and effective governance. If the tone set by the management is lax, then fraudulent financial reporting about working capital operations is more likely to occur. In Public sector, entities normally have governing boards which help in setting up policies and procedures for effective management of working capital. However, according to Gyebi \& Quani (2013) most public institutions do not have a good internal financial control system on cash collections and expenditure which jeopardizes the process of working capital management.

\subsection{Risk Assessment Process and Working Capital Management}

Risk Assessment involves identification and analysis of relevant risks to enable an organization achieve objectives which forms a basis for determining how the risk will be mitigated. Risk assessment highlights the importance of management carefully, identifying and assessing all the factors that hinder it from achieving organizational objectives (Asiligwa, 2017). An entity's risk assessment process involves identifying and responding to organizational threats. For financial reporting purposes, the entity's risk assessment process includes how management identifies risks relevant to the preparation of financial statements that give a true and fair view (or are presented fairly, in all material respects) in accordance with the entity's applicable financial reporting framework, estimates their significance, 
assesses the likelihood of their occurrence, and decides upon actions to manage them. For example, the entity's risk assessment process may address how the entity considers the possibility of unrecorded transactions or identifies and analyzes significant estimates recorded in the financial statements. Risks relevant to reliable financial reporting also relate to specific events or transactions. Risk assessment is vital in management of working capital because it entails assessing all operations systems to ensure that deficiencies are eliminated. According to Badoo, Hammond \& Oppong (2020), Public institutions are normally required to undertake risk assessment, select and develop control activities, deploys policies and procedures geared towards mitigating fraud and error. Chandra (2002) argues that institutions require establishment of modern yardsticks to regulate fraud-related risks since they are everywhere and surrounds our personal activities or professional lives. Though it is difficult to eliminate completely, one can minimize risk by employing risk assessment techniques in his personal and professional capacity.

The risk identification stage has a role to play in the success of working capital management in a public entity because this forms a basis upon which financial controls can be strengthened to ensure efficiency in operations (Gyebi \& Quani, 2013). Knowledge about the strengths and weaknesses of other internal controls is also important for the risk identification of financial performance of a public University. So a systematic procedure for risk identification has to be developed by a University and it differs from University to University. There are various forms of risks faced by public universities. It is very important to understand the various forms of risk faced by Public Universities such as liquidity risk, regulatory risk, credit risk, operating risk strategic risk, price (equity risk) residual risk, settlement risk, solvency risk, country (political risk), legal risk and reputation risk. A thorough understanding of these risks by the managers could enable them to prepare for the unforeseen circumstances (Khan, 2008).

\subsection{Control Activities and Working Capital Management}

Control activities are policies and procedures established and executed to ensure that management directives about the operations of an entity are carried out properly and in a timely manner (Agyapong, 2017). This is done to reduce operational risks and ensure that the organization achieves its intended objectives. In public sector, control activities basically comprise; performance reviews (comparing actual performance with budgets, forecasts and prior period performance), information processing, physical controls (necessary to provide security over both records and other assets) and segregation of duties where no one person should handle all aspects of a transaction from the beginning to the end (Ejoh \& Ejom, 2014). This is vital in working capital management in Universities especially in cash and credit management where control activities are needed to ensure that every transaction is authorized and recorded. Therefore, for effective working capital management which ensures that all public funds are properly utilized and accounted for as per well-established guidelines, control policies and procedures are needed to enforce this. This argument is supported by Romney and Steinbart (2009) who state that in order to achieve effectiveness and efficiency in the workplace, it is most essential to ensure that control activities are well implemented.

\subsection{Budgetary Control and Working Capital Management}

Budgets are quantitative and financial plans made indicating entity's expected receipts and expenditure. Budgetary controls are mechanisms put in place to ensure that financial resources are raised and utilized based on well laid procedures. Budgeting and budgetary control is also a mechanism of establishing budgets relating to the responsibilities of management as per the requirement of the organizational policies (Usuman et al., 2016). When a budgeting and control system is in use, budgets are established which set out objectives in financial terms. Continuous comparison is made between the actual and budgeted results, which are intended to either secure, thorough action of managers, the objectives of policy or to even provide a basis for policy revision.

According to Bartle (2008) budgets today provide a focus for the organization, aid in the coordination of activities and facilitates control. The implication of this is that without effective budgetary controls, an enterprise cannot efficiency manage its working capital resources and therefore its liquidity position will be compromised. The entity will fail to manage its day-today operations. The entity's budgetary control system enhances planning and controlling of all funds hence facilitating decision making on the prepared revenue and expenditure variance analysis. Hongren and Foster (2012) argue that effective implementation of budgets contributes to the good financial performance of an entity. The dedicated work force, improved technology and effective policies (budgeting inclusive) enable public Institutions to remain effective and efficient in fulfilling their stewardship obligations to the stakeholders.

\section{Study Design and Methodology}

The study design is cross sectional using a quantitative approach. The target population includes members of Finance and Internal Audit Directorates, and heads of departments, Schools and colleges at Makerere University. These are purposively selected because of the role they play in establishment and implementation of internal control policies. A 
total sample of 104 respondents is used and determined based on Krejcie and Morgan's table (1970) of sample selection (Sekaran, 2006). Respondents were selected using stratified and simple random sampling techniques. Data was collected using a self-administered closed ended questionnaire designed based on research objectives. Questions were structured using a 5 Point-Likert scale range which include; strongly disagree (1), disagree (2), not sure (3), agree (4) and strongly agree (5). The dependent variable is working capital management while the independent variable is effectiveness of internal financial controls whose constructs include control environment, risk assessment, control activities and budgetary control. The questionnaire was first pre-tested to establish the degree of reliability and validity of constructs and items used in data collection using Cronbach Alpha values and Content validity index. Results of Cronbach Alpha values are presented in Table 1.

Table 1. Cronbach's coefficients alpha

\begin{tabular}{lll}
\hline No. & Variables & Cronbach Alpha values \\
\hline 1 & Working capital & 0.760 \\
\hline 2 & Control Environment, & 0.839 \\
\hline 3 & Risk Assessment Process, & 0.786 \\
\hline 4 & Internal Audit & 0.751 \\
\hline 5 & Budgetary Control & 0.823 \\
\hline
\end{tabular}

Source: Primary data

All the Cronbach Alpha values are above 0.5 and consistent with Daud et al. (2018) who state that Cronbach Alpha values above 0.8 shows that the reliability of data collection instrument is strong and Alpha values ranging 0.6-0.8 are considered moderate but acceptable. Validity was measured using item content validity index (I-CVI) for all the items used in the questionnaire. The instrument was given to two experts to give opinions on the relevance of the questions using a four-point scale ranging from not relevant (1), somewhat relevant (2), quite relevant (3) and highly relevant (4). The I-CVI's were computed by obtaining the ratio of the number of those who scored 3 and 4 to the total number of the items of the data collection instrument and the results were 0.846 and 0.808 for experts one and two respectively. These results indicate that the data collection instrument is valid and are supported by Rodrigues et al. (2017) who state that an I-CVI of 0.78 shows that the validity of the instrument is high. Data analysis is carried out using the Statistical Package for Social Sciences (SPSS) quantitative reports for descriptive statistics, Pearson's correlations and multiple regressions tests. The following regression equation is used in this study.

$\mathrm{Y}=\beta_{0}+\beta_{1} X_{1}+\beta_{2} X_{2}+\beta_{3} X_{3}+\beta_{4} X_{4}+\varepsilon$ where

$\beta_{0}=$ Constant parameter

$\beta_{1}$, to $\beta_{4}=$ Coefficient of the independent variables/regression parameters

$\mathrm{Y}=$ Working capital management

$\mathrm{X}_{1}=$ Control environment

$\mathrm{X}_{2}=$ Risk assessment

$\mathrm{X}_{3}=$ Control activities

$\mathrm{X}_{4}=$ Budgetary control

$\varepsilon=$ Probabilistic error term

\section{Main Findings and Discussion}

The results are presented based on study objectives. Descriptive statistics are generated to assess the strength of internal financial controls while results of Pearson's correlation and regression tests are used to analyze the relationship between internal financial controls and working capital management. 


\subsection{Descriptive Statistics for Internal Financial Controls}

Table 2. Control environment

\begin{tabular}{lcc}
\hline & $\begin{array}{c}\text { Mean } \\
\text { Standard } \\
\text { Deviation }\end{array}$ & 1.079 \\
\hline Management is committed to efficient utilization of financial resources. & 4.205 & 0.837 \\
\hline $\begin{array}{l}\text { Management financial decisions and practices are carried out with a great deal of } \\
\text { integrity. }\end{array}$ & 4.96 & 1.060 \\
\hline The University has a sound accounting and financial management systems. & 3.16 & 0.898 \\
\hline \begin{tabular}{l} 
Staff members receive adequate awareness on the issues of financial management. \\
\hline There are policies and procedures in place to protect against misuse of financial resources.
\end{tabular} & 4.33 & 1.199 \\
\hline $\begin{array}{l}\text { The University's organizational structure supports effective financial resources } \\
\text { management. }\end{array}$ & 3.02 & 1.117 \\
\hline
\end{tabular}

Source: primary data

Results in Table 2 show that management is committed to efficient utilization of financial resources $(\mathrm{Mean}=4.205$, Standard deviation $=1.079$ ). This implies that management is committed to ensure that funds of the operations are not mismanaged. The University also has a sound accounting and financial management systems $($ Mean $=4.02$, Standard deviation= 1.060) and there are policies and procedures in place to protect against misuse of financial resources $($ Mean $=4.33$, Standard deviation=1.199). These indicate that the University operates a clear financial system with laid out policies and procedures to ensure that resources are effectively used. However, findings show that respondents were not sure whether staff members receive adequate awareness on the issues of financial management $($ Mean $=3.16$, Standard deviation $=0.898$ ) and whether the University structure supports effective financial resource management $($ Mean $=3.02$, Standard deviation $=1.117)$. These raises pertinent concerns because according to Agyapong $(2017)$, implementation of internal control system is affected by organizational structures as well as management information systems designed to help an organization achieve targeted objectives. The respondents also disagreed with the opinion that management financial decisions and practices are carried out with the great deal of integrity $($ Mean $=2.96$, Standard deviation $=0.837$ ). This contrasts Sambo \& Benneth $(2018)$ who assert that the proper functioning of any internal control system depends on integrity and competence of those operating it.

Table 3. Risk assessment process

\begin{tabular}{llc}
\hline & Mean & $\begin{array}{c}\text { Standard } \\
\text { Deviation }\end{array}$ \\
\hline There is a clear criterion of identifying fraud-related risks in the institution. & $3 . .74$ & 1.123 \\
\hline $\begin{array}{l}\text { There are controls and mechanisms in place for mitigation of critical financial risks } \\
\text { that may occur due to fraud }\end{array}$ & 4.00 & 1.012 \\
\hline $\begin{array}{l}\text { Management carries out periodical risk assessment on day-today financial } \\
\text { operations to achieve objectives in this Institution }\end{array}$ & 3.99 & 1.093 \\
\hline Management reviews financial transactions regularly. & 2.81 & 1.098 \\
\hline The institution regularly assesses risks associated with cash and credit transactions & 4.35 & 1.009 \\
\hline
\end{tabular}

Source: Primary data

Results in Table 3 reveal that there is a clear criteria of identifying fraud related risks in the institution $($ Mean $=3.74$ Standard deviation $=1.123$ ). There are also controls and mechanisms to mitigate critical financial risks that may occur due to fraud $($ Mean $=4.00$, Standard deviation $=1.012)$. The results imply that there are mechanisms and risk 
assessment processes in place to prevent occurrence of frauds. This is consistent with Wakiriba, Ngahu \& Wagoku (2014) that institutions should have clear risk assessment mechanisms to ensure all financial transactions are recorded to prevent errors and fraud and to safeguard company assets. Findings show that the institution regularly assesses risks associated with cash and credit transactions (Mean $=4.35$, Standard deviation=1.009). This is important to ensure that there are controls in place to prevent risks and to ensure that the entity's cash balances are properly handled. However, respondents disagreed about management reviewing financial transactions regularly. This is an important financial control that ensures proper use of working capital.

Table 4. Control activities

\begin{tabular}{lcc}
\hline & $\begin{array}{c}\text { Mean } \\
\text { Standard } \\
\text { Deviation }\end{array}$ \\
\hline There's effective supervision of all financial operations of the university & 3.13 & 0.996 \\
\hline $\begin{array}{l}\text { There is adequate segregation of duties in the institution's finance and accounts } \\
\text { departments. }\end{array}$ & 4.28 \\
\hline There are policies in place to ensure authorization and approval of financial transactions & 4.09 & 0.951 \\
\hline Duties are periodically rotated & 3.24 & 0.980
\end{tabular}

Source: Primary data

Results in Table 4 show that there is adequate segregation of duties (Mean $=4.28$, Standard Deviation $=0.951$ ). This is an important internal financial control that helps to attach responsibility for financial transactions. There are also policies in place to ensure authorization and approval of financial transactions $($ Mean $=4.09$, Standard deviation $=$ 0.876). Consistent with Ejoh \& Ejom (2014), clear segregation of duties, completeness and clear authorization processes are strong internal control activities that enhance efficiency and transparent operations of an organization. However, the findings show that respondents are not sure about the existence of effective supervision of all financial operations $($ Mean $=3.13$, Standard deviation $=0.996)$ and whether duties are periodically rotated $($ Mean $=3.24$, Standard deviation $=0.980)$.

Table 5. Budgetary controls

\begin{tabular}{lcc}
\hline & $\begin{array}{c}\text { Mean } \\
\text { Standard } \\
\text { Deviation }\end{array}$ & 1.101 \\
\hline Controls are in place to check excess expenditure of funds. & 4.05 & 3.56 \\
\hline There is a budgetary monitoring framework for effective use of public funds. & 4.021 \\
\hline $\begin{array}{l}\text { There controls in place to ensure that financial resources are realized and spent based on } \\
\text { budget estimates. }\end{array}$ & 4.043 \\
\hline Budget plans are properly coordinated to ensure effective use of operations funds & 1.030 \\
\hline Budgetary control mechanisms are evaluated periodically to ensure clear implementation & 2.86 & 1.077 \\
\hline
\end{tabular}

Source: Primary data

Findings in Table 5 show that there are controls in place to check excess expenditure of funds $($ Mean $=4.05$, Standard deviation $=1.101$ ). This implies that there are mechanisms in place to ensure that public funds are properly utilized. This is consistent with Olaoye \& Ogunmakin (2014) that Governments use budgets as a guiding tool for planning and control of resources. Results also reveal that respondents are not sure of the existence of a budgetary monitoring framework for effective use of public funds (Mean $=3.56$, Standard deviation $=1.021$ ). The study establishes that there are controls in place to ensure that financial resources are realized and spent based on budget estimates $($ Mean $=4.17$, Standard deviation $=1.043$ ). Budgetary plans are properly coordinated to ensure effective use of operational funds $($ Mean $=4.34$, Standard deviation $=1.030)$. The findings are supported by Agbenyo, Danquah \& Shaungshuang $(2018)$ 
that coordination of budgetary activities is vital because it ensures that there is effective use of financial resources which enhances financial performance.

\subsection{Correlations Analysis}

Table 6. Results of Pearson Correlation Analysis

\begin{tabular}{|c|c|c|c|c|c|}
\hline & $\begin{array}{l}\text { Control } \\
\text { environment }\end{array}$ & $\begin{array}{l}\text { Risk assessment } \\
\text { process }\end{array}$ & $\begin{array}{l}\text { Control } \\
\text { activities }\end{array}$ & $\begin{array}{l}\text { Budgetary } \\
\text { controls }\end{array}$ & $\begin{array}{l}\text { Working capital } \\
\text { management }\end{array}$ \\
\hline Control environment & 1.000 & & & & \\
\hline \multirow{2}{*}{$\begin{array}{l}\text { Risk assessment } \\
\text { process }\end{array}$} & $0.329 *$ & 1.000 & & & \\
\hline & 0.035 & & & & \\
\hline \multirow[t]{2}{*}{ Control activities } & $0.412 * *$ & $0.237 *$ & 1.000 & & \\
\hline & 0.005 & 0.045 & & & \\
\hline \multirow[t]{2}{*}{ Budgetary controls } & 0.256 & $0.197 * *$ & 0.319 & 1.000 & \\
\hline & 0.082 & 0.002 & 0.069 & & \\
\hline \multirow{2}{*}{$\begin{array}{l}\text { Working capital } \\
\text { management }\end{array}$} & $0.432 * *$ & $0.390 * *$ & -0.273 & $0.446 * *$ & 1.000 \\
\hline & 0.002 & 0.000 & 0.114 & 0.000 & \\
\hline
\end{tabular}

\footnotetext{
${ }^{* *}$ Correlation is significant at 0.01 level (2-tailed)

*Correlation is significant at 0.05 level (2-tailed)
}

Source: Primary data

The preliminary findings in Table 6 above show that the control environment and working capital management have a positive relationship that is significant at $1 \%$ level of significance $(r=0.432 \mathrm{p}$ value 0.002$)$. This implies that the institution has an internal control structure for assigning authority and responsibility to ensure proper management of working capital. This results into effective use of financial resources for the entity's day-today operations. Similarly, the findings indicate that the relationship between the institution's risk assessment process and working capital management is positive and significant at $1 \%$ level of significance $(r=0.390, p$ value 0.000$)$. This implies that the institution's systems of identifying and analyzing risks are related with improvements made in working capital operations. The results further indicate that the relationship between budgetary controls and working capital management is positive and significant at $1 \%$ level $(\mathrm{r}=0.446, \mathrm{p}$ value 0.000$)$. This is consistent with Olaoye \& Ogunmakin, (2014) that budget plans and monitoring systems help organizations to exercise control over people, revenues and costs and ensure efficient use of organizational resources. The relationship between control activities and working capital management is insignificant.

\subsection{Regression Analysis}

Table 7. Multiple regression tests

\begin{tabular}{|c|c|c|c|c|c|}
\hline \multirow[t]{2}{*}{ Model } & \multicolumn{2}{|c|}{ Unstandardized Coefficients } & Standardized Coefficients & \multirow[t]{2}{*}{ T-stat } & \multirow[t]{2}{*}{ Sig. } \\
\hline & $\mathrm{B}$ & Std. Error & Beta & & \\
\hline (Constant) & 2.607 & 0.251 & & 10.382 & 0.000 \\
\hline Control environment & 0.177 & 0.087 & 0.216 & 2.033 & 0.045 \\
\hline Risk assessment process & 0.302 & 0.084 & 0.365 & 3.596 & 0.001 \\
\hline Control activities & -0.168 & 0.112 & -0.180 & -1.517 & 0.134 \\
\hline Budgetary controls & 0.226 & 0.081 & 0.295 & 2.808 & 0.006 \\
\hline
\end{tabular}

Dependent variable: working capital management

\begin{tabular}{llll}
\hline $\mathrm{R}$ Square $=0.133$ & Adjusted $\mathrm{R}^{2}=0.123$ & F change $=12.929$ & Sig. F change $=0.001$ \\
\hline Source: Primary data &
\end{tabular}

Source: Primary data 
Findings from regression tests in table 7 above show that control environment has a significant positive effect on working capital management $(\beta=0.177, \mathrm{p}$ value 0.045$)$. This means that the internal control environment which includes management attitudes, procedures and policies put in place leads to improvements in working capital management. The results are supported by Wakiriba Ngahu \& Wagoku (2014) who argue that managerial controls, attitudes and policies of financial decisions and transactions of public institutions related to revenues, expenditure, assets and liabilities are central to effective and efficient utilization of available resources. This ultimately enhances management of working capital. Empirical results also indicate that risk assessment has a positive and significant effect ( $\beta=0.302 \mathrm{p}$ value 0.001). This is consistent with Sambo \& Benneth (2018) who assert that a regular process of risk assessment improves working capital by enabling management to minimize corruption, misappropriation and embezzlement of public funds and risk of fraud. This implies that a continuous risk assessment process prevents risk of financial loss through misappropriations of revenues and expenditure which are vital elements of working capital management. The results are also supported by Kabuye et al. (2019) who state that an organization should regularly ensure a favorable control environment, an effective risk assessment and strong control activities in day-today operations to enhance financial performance. However, the empirical findings show that the effect of control activities is insignificant.

The results further indicate that budgetary control has a positive significant effect on working capital management $(\beta=$ 0.226 , $p$ value 0.006 ). This implies that an effective budgetary control system ensure that public institutions put in place mechanisms that enhance effective utilization of public funds hence enhancing working capital management. The findings are consistent with Agbenyo, Danquah \& Shaungshuang (2018) who argue that a good budgetary control system will enable adequate allocation and utilization of resources needed for working capital to meet organizational goals and maximize performance.

\section{Conclusion, Implications and Contribution}

The aim of the study was to examine the extent to which internal financial controls affect working capital management in public Universities in Uganda. The elements of internal financial controls used in this study include; the control environment, risk assessment process, control activities and budgetary control. We establish that the control environment, risk assessment process and budgetary control have a positive significant effect on working capital management. The study finds no evidence to suggest that the effect of control activities is statistically significant. The implication of the findings is that having a strong control environment where institutional management attitude is geared towards improving the integrity and ethical values of the organization's system leads to improvement in management of working capital. Furthermore, risk assessment processes ensure that risks of fraud and misappropriation or mismanagement of public funds are prevented which improves working capital management. The findings also imply that an effective budgetary control enhances the monitoring process to ensure effective utilization of financial resources which ultimately improves the way working capital of an organization is managed.

The study contributes to literature in public sector by pointing out mechanisms of improving working capital management through strengthening the internal control systems. It helps to establish elements of internal financial controls relevant for managing public funds generated from internal sources, Government and donations. The study sets out a model of internal financial controls that can be used by Public Universities to manage working capital. The limitation of the study is that it used a sample from one Public University. Although this is the oldest and biggest Public University in Uganda and also one of the top ranked Universities in Africa, it is recommended that future studies be extended to other Universities to fully understand the effectiveness of internal financial controls in all Public Universities.

\section{References}

Agbenyo, W., Danquah, F. O., \& Shaungshuang, W. (2018). Budgeting and its effects on financial performance of listed manufacturing firms: Evidence from manufacturing firms listed on Ghana Stock Exchange. Research Journal of Finance \& Accounting, 9(8), 12-22.

Agyapong, K. E. (2017). Internal control activities as a tool for financial management in public sector: A case study of Ghana Post Company Limited. Journal of the Advancement of Developing Economies, 6(1), 43-77.

Allis, R. P. M. (2004). Financial Management: Ratio Analysis Zero to one Million. New York: McGraw-Hill.

Asiligwa, G. R. (2017). The effect of internal controls on financial performance of commercial banks in Kenya. IOSR Journal of Economics and Finance, 8(3), 92-105. https://doi.org/10.9790/5933-08030492105 
Auditor General. (2016). Report and Opinion of the Auditor General on the Financial statements of Makerere University for the financial year ended 30th June, 2016. Retrieved from http://www.oag.go.ug/wp-content/uploads/2017/08/MAKERERE-UNIVERSITY

Badoo, D. O., Hammond, H., \& Oppong, F. (2020). Assessment of Internal control systems of Technical Universities in Ghana. Journal of Finance \& Accounting, 8(2), 64-72.

Bartle, J. (2008). Determinants of weaknesses in internal control over financial reporting and the implications for earnings quality. Journal of Internal Audit, 2(3), 50-65.

Block, F., \& Geoffrey, A. (2008). A basic study of agency cost source and municipal use of internal versus external control. Accounting and Business Research. Journal on Financial Management, 3(2), 12-19.

BMAU Briefing paper. (2018). Funding of Public Universities in Uganda. What are issues?. Retrieved from https://www.finance.go.ug/sites/default/files/BMAU Policy Brief 24-18

Chandra, P. (2002). Investment Analysis and Portfolio Management. Tata McGraw Company.

Cohen, P. (2002). Factors determining the internal audit quality in banks: Empirical Evidence from Jordan. International Research Journal of Finance and Economics, 73, 99-108.

Daud, K. A. M., Khidzir, N. Z., Ismail, A. R., \& Abdullah, F. A. (2018). Validity and reliability of the instrument to measure social media skills among small and medium entrepreneurs at Pengkalan Datu River. International Journal of Development and Sustainability, 7(3), 1026-1037.

Ejoh, N., \& Ejom, P. (2014). The impact of internal control activities on Financial performance of Tertiary Institutions in Nigeria. Journal of Economics and Sustainable Development, 5(16), 133-143.

Gyebi, F., \& Quain, S. (2015). Internal control on cash collection. A case of Electricity company of Ghana ltd, Accra East Region. International Journal of Business and Social Science, 4(9), 217-233.

Hayles, R. (2005). Principles of Auditing. California, Pearson Education ltd.

Hongren, C. T., \& Foster, G. (2012). Cost Ac-counting: a managerial emphasis. New Jersey, Prentice Hall Inc.

Kabuye, F., Akugizibwe, I., Kato, J., \& Bugambiro, N. (2019). Internal control systems, working capital management and financial performance of supermarkets. Cogent Business and Management, 6, 1-18. https://doi.org/10.1080/23311975.2019.1573524

Kalagbor, K. G., Nyime, O., \& Aloy-Ezirim, H. (2018). Internal control practices and cash flow management of organizations. Ceka International Journal of Finance and Management Sciences, 5(2), 1-12.

Khan, J. (2008). Risk assessment in Public entities: on its way to globalization. Managerial.

Kyaligonza, R., Kimoga, J., \& Nabayego, C. (2015). Funding of academic staff's research in Public Universities in Uganda: Challenges and opportunities. Makerere Journal of Higher Education, 7(2), 147-162.

Laughlin, R. C. (1980). External Financial Control Systems: Theory and Application. Managerial Finance, 6(1), 32-51. https://doi.org/10.1108/eb013459

Leibenstein, H. (1993). Organizational or friction equilibria X-efficiency and the rate of Innovation. Quarterly Journal of Economics, 8(3), 600-623.

Nakayiwa, T. (2012). Financial management of public and private universities in Uganda.

Olaoye, F. O., \& Ogunmakin, A. A. (2014). Budgetary control and performance in the Public Corporations in Osun State. IOSR Journal of Humanities and Social Sciences, 19(7), 59-62. https://doi.org/10.9790/0837-19745962

Richie, M. (1989). The Impact of Enterprise Resource Planning (ERP) Systems on the Effectiveness of Internal Controls over Financial Reporting. Journal of Information Systems, 5(1), 19-29.

Rodrigues, I. B., Adachi, J. D., Beattie, K. A., \& MacDermid, J. C. (2017). Developing and validation of a new tool to measure facilitators, barriers and preferences to exercise in people with Osteoporosis. BMC Musculoskeletal Disorders, 18(540), 1-9. https://doi.org/10.1186/s12891-017-1914-5

Romney, M., \& Steinbart, P. (2009). Accounting information systems (11th ed.). New Jersey, Pearson Prentice Hall.

Sambo, F., \& Benneth, U. I. (2018). Internal control system as a mechanism for effective fund management of Universities in Bayelsa State, Nigeria. Global Journal of Social Sciences, 17, 77-91. https://doi.org/10.4314/gjss.v17i1.8 
Sekaran, U. (2006). Research Methods for Business: A skill building approach. John Wiley and Sons.

Tejmani, S. N., \& Moirangthem, B. S. (2013). Working capital management: An essential tool of Business Finance- A case study of National Plastic Industries limited (NPIL). IOSR Journal of Business Management, 12(2), 1-7. https://doi.org/10.9790/487X-1220107

Usuman, S. A., Yusufari, M. Y., Hamza, A., \& Abdullahi, S. R. (2016). The effect of Budgeting and Budgetary control in Local Government Administratiion of Nigeria. European Journal of Business and Management, 8(22), 135-140.

Wakiriba, J., Ngahu, E., \& Wagoki, K. (2014). The Contribution of Internal Auditing to Management. International Journal of Management Research and Technology, 3(2), 17-22.

Whittington, R., \& Pany, K. (2004). Principles of auditing and other assurance services. Boston, MA: McGraw-Hill/Irwin.

Woolf, E. (1994). Auditing today. New York: Prentice Hall. 